\title{
Antifungal potential of some medicinal plants on selected pathogenic fungi
}

\begin{abstract}
Introduction: Medicinal plants represent a rich source of antimicrobial agents. Plants are used medicinally in different countries and they are source of many potent and powerful drugs. A wide range of medicinal plant parts is used for extract as raw drugs.

Objective: The antifungal activity of different medicinal plant Methanol extracts for three different plant was selected for this studies. These plants were Leptadenia hastata, Barringtonia racemosa and Barringtonia asiatica. The aim of this test is to find out the efficacy of the plants against some selected pathogen. this may help in the discovery of new chemical classes of antifungal and also serve as selective probiotic agents, when administered in adequate amounts, confer a health benefit on the host
\end{abstract}

Material and methods: Leptadenia hastata, Barringtonia asiatica and Barringtonia racemosa extracts were tested for potential antifungal properties. The roots were extracted with methanol solvent and then vaporized to give respective extracts. The antimicrobial activity against Aspergillus niger, Aspergillus flavin, Candida tropicalis and Fusarium oxysporium (fungi) was determined by agar desk method. The optical densities of the broth using UV mini spectrophotometer and zone of inhibition by the crude extracts were determined.

Results: the results showed the efficacy of the plants extracts at different concentration with varying data, higher rate of inhibition was observed in all the extract against all the fungi species. However, extract from Leptadenia hastata showed more significant inhibition with diameter rate with $3.38 \pm 0.08$ to $5.00 \pm 0.09$ days five for $25 \mathrm{ppm}$ to $250 \mathrm{ppm}$, while Barringtonia racemosa and Barringtonia asiatica lesser compared to Leptadenia hastata as against the pathogen at the same concentration and same time frame.

Conclusion: It is showed that all plants extract was found maximally affected against the activity of Aspergillus niger, Aspergillus Flavin, Candida tropicalis and Fusarium oxysporium and aggressively inhibits the growth of species in various plant extracts. This may help in the discovery of new chemical classes of antifungal as well as antibiotic that could serve as selective agents for the maintenance of human health and may provide biochemical tools for the study of fungal infectious diseases.

Keywords: fungi, pathogenic, leptadenia hastata, barringtonia racemosa, barringtonia asiatica

\author{
Volume 7 Issue 5 - 2018 \\ Isaac John Umaru,' Fasihuddin A Badruddin,' \\ Hauwa A Umaru, ${ }^{2}$ Kerenhappuch I Umaru ${ }^{3}$ \\ 'Faculty of Resource Science and Technology, University of \\ Malaysia Sarawak, Malaysia \\ ${ }^{2}$ Department of Biochemistry, Moddibo Adama University Yola, \\ Nigeria \\ ${ }^{3}$ Department of Biochemistry, University of Maiduguri, Nigeria
}

Correspondence: Isaac John Umaru, Faculty of Resource Science and Technology, University of Malaysia Sarawak, Kuching, 94300, Kota Samarahan Malaysia, Email umaruisaac@gmail.com

Received:September 12 2018 | Published: September 19, 2018

\section{Introduction}

Medicinal plants represent a rich source of antimicrobial agents. Plants are used medicinally in different countries and they are source of many potent and powerful drugs. A wide range of medicinal plant parts is used for extract as raw drugs. They possess varied medicinal properties, while some of these raw drugs are collected in small quantities by the local communities and traditional healers for local use. ${ }^{1}$ The plants represent a rich source iiof antimicrobial agents. ${ }^{2,3}$ Many of the plant materials used in traditional medicine are readily available in rural areas at relatively cheaper than modern medicine. ${ }^{4-6}$ The activity of plant extracts on bacteria and fungi has been studied by a very large number of researchers in different parts of the world. ${ }^{7-9}$ The plant metabolites and plant based pesticides appear to be one of the better alternatives as they are known to have minimal environmental impact and danger to consumers in contrast to the synthetic drugs. ${ }^{10,11}$ Leptadenia hastata (Pers) Decne (Family-Asclepiadaceae), commonly known as hastata is edible non-domesticated vegetable and it is collected in wild throughout Africa. It is a voluble herb with creeping latex stems, glabescent leaves, glomerulus and racemus flowers as well as follicle fruits. It is typically grown in tropical dry lands in sandy soil. Wild foods like Leptadenia hastata provide food security during seasonal changes and are used medicinally in many areas. The breeders commonly used the leaf and stems for their parasitic activity and against placental retention. ${ }^{12}$ This plant can be used as a probiotic supplements and foods to lower risk of infections, improved digestion and even a reduced risk for some chronic diseases as claimed by traditional healer. ${ }^{12}$ However, Barringtonia racemosa are mangrove plants. This specie which is also known as putat, fish poison tree or powder puff tree is a type of highly valuable plant species due to its medicinal values. They are geographically found to be widely distributed from eastern Africa and Madagascar to Micronesian, Asia and Polynesian Island, the species was said to have been associated very well in various tribes around the world with diverse ethno-botanical uses. The therapeutic potential of this herb is as a result of the presence of diverse bioactive compounds such as Lupeol, Germanicol, Teraxanol Barringtogenic, Barringtogenol etc. However, most of the studies on Barringtonia racemosa are restricted to crude extracts, and many biologically active compounds are yet to be identified in order to claim the traditional uses of this 
plant as acclaimed by the herbal and traditional practitioners. ${ }^{13}$ While Barringtonia asiatica is one among the species belonging to the family Barringtonia, it is a native to mangrove habitats on the tropical, it is a common plant in the Malaysian Mangroves and wetlands such as the Kuching wetlands Sarawak and Bako National Park, it is also found in tropical Africa, Nigeria and Madagascar. ${ }^{14}$

\section{Material and method}

\section{Plant preparation}

Freshly harvested leaves of Leptadenia hastata, Barringtonia racemosa and Barringtonia asiatica were used for the preparation of the crude extract. Leptadenia hastata was collected from an uncultivated farm in Nigeria, while the other two species where collected in Sarawak Malaysia. This three important medicinal plants were selected based on the traditional claim of their efficacy against some antimicrobial and antifungal activity. The plants were collected and washed with distilled water. These plants leaves were dried at and their different parts were grinded to form powder extract. Screening bioassay preparation of plant extract was conducted in lab condition. For this purpose, $150 \mathrm{mg}$ of the powdered leaves were weighed into a beaker and mixed with distilled water three times the quantity of the sample and allow to stand for two days with continues shacking at time interval for $12 \mathrm{hrs}$. The mixture was then filtered using Whatman filter paper No.4 and the solvent was then evaporated using a rotary evaporator (Heldolph Laborato 400). It was then stored under frozen condition for further use.

\section{Reconstitution of the extracts}

$2 \mathrm{~g}$ of each of the plants the extract was weighed and dissolved in $20 \mathrm{ml}$ of $50 \%$ Dimethyl sulfoxide (DMSO) to make a stock concentration of $100 \mathrm{mg} / \mathrm{ml}$ from which the various concentrations used were calculated.

\section{Microorganisms used}

Isolates of Aspergillus flavin, Aspergillus niger, Candida tropicalis, and Fasarium oxysporium from four different Concentration were used. They were collected from the virology Laboratory Faculty of Resource science, Universiti Malaysia Sarawak.

\section{Drug used}

Fluconazole common name Diflucan was used as reference standard for antifungal studies obtained from Medical Resource Sarawak . The disc of $5 \mathrm{~mm}$ diameter of different fungi 6days old culture were prepared and smeared of the Petri plates. Three replicates were kept for each treatment and incubated at $28 \pm 2^{\circ} \mathrm{C}$. The radial growth of mycelium to ascertain the effect of the plants were measured every day for five to six days and compared with the results of control.

\section{Result and discussion}

\section{Result}

Result obtained from the studies is presented in Tables 1-3 this revealed that all the fungal species were affected by the administration of Leptadenia hastata, Barringtonia racemosa and Barringtonia asiatica in a dose dependent manner. The inhibition of the microorganism significantly increases at $(\mathrm{P}<0.05)$ at 50ppm 100ppm, $500 \mathrm{ppm}$ and in some instances when compared with control.

\section{Discussion}

The result obtained as presented in Tables 1-3 shows that the methanol root extract of the plant Leptadenia hastata, Barringtonia racemosa and Barringtonia asiatica were effective in significantly reducing the growth rate of some of the selected pathogen as compared to the control. However, all the roots extract showed antifungal activity against Aspergillus niger, Aspergillus flavus, Candida tropicalis and Fasarium oxysporium with maximum inhibition $(\mathrm{mm})$ recorded in Candida tropicalis, Fusarium oxysporium and Aspergilus flavus $(1.95 \pm 0.05 \mathrm{~mm}, 1.80 \pm 0.06 \mathrm{~mm}$ and $5.00 \pm 0.09 \mathrm{~mm})$ higher compared to the control in all concentration on each fungi on the same days. The antifungal activities of the methanol extract of Leptadenia hastata were observed in various concentrations with zones of inhibition diameters ranging from $1.23 \pm 0.15 \mathrm{~mm}$ to $3.75 \pm 0.05 \mathrm{~mm}$. Among the six concentrations, $100 \mathrm{ppm}$ was the most active with $3.75 \pm 0.05 \mathrm{~mm}$ when compared to the control rate activity on the pathogen. The extracts inhibited the growth of Aspergillus niger at all concentration except at $500 \mathrm{ppm}$ and $1000 \mathrm{ppm}$ which indicated less active as when compared with the control as well as the other concentration showed in Table 1. However, in Table 2 the methanol root extract of Barringtonia racemosa decreased the mycelial growth of all the pathogen with increasing of dose concentration. The highest result impact was observed in Fusarium oxysporium. the concentration of the extract at $1000 \mathrm{ppm}$ completely if not all inhibited the growth of Fusarium oxysporium. Concentration of the extract at 25 to $100 \mathrm{ppm}$ has the least effect on the mycelial growth of the fungi in general. This shows that the pathogen has been adversely affected by the increase in concentration of the methanol root extract. This difference in inhibition rate might be as a result diversity of the pathogens and also selectivity properties of chemical substance as well as dose concentration and mechanism of action of the component with time duration. Table 3 Indicated the antifungal activity of the extracts of Barringtonia asiatica from six different concentration of the methanol extracts. The result of the MIC studies revealed the anti-fungal activity of the extracts against the tested strain of the microorganism between concentration ranges of $25 \mathrm{ppm}, 50 \mathrm{ppm}, 100 \mathrm{ppm}, 250 \mathrm{ppm} 500 \mathrm{ppm}$ to $1000 \mathrm{pp}$. The result of zone of inhibition study revealed that the extracts possess anti- fungal activity in concentration dependent manner against the test organism and was comparable with the standard drug.

Mean \pm SD yield of various extracts concentration confirm that $100 \mathrm{ppm}$ of the extracts has minimum yield with $0.85 \pm 0.05$ at day one and maximum yield at $3.17 \pm 0.05$ day five for the pathogen especially Aspergillus niger, were as Aspergillus flavin has maximum inhibition at $3.78 \pm 0.04$. however, Barringtonia racemosa extract was found to be less active against Aspergillus niger but showed significant inhibition on Candida tropicalis and Fusarium oxysporium when compared with the Leptadenia hastata as well as the sister species Barringtonia asiatica at the same time and as well as concentration as shown in tables above. Though the extract exhibits its potency against all the pathogen. The Barringtonia asiatica methanol has higher effect on broad spectrum compared to Barringtonia racemosa because of its significant activity on all the pathogen at concentration 100,250 , and $500 \mathrm{ppm}$ thus the extracts impart significant antifungal activity against all test strains. This suggests that the plant parts of Leptadenia hastata and Barringtonia a asiatica have a broad spectrum of activity compared to Barringtonia racemosa, although the degree of susceptibility could differ between different organisms. The broad spectrum of antifungal activity found in this present study may be attributed to the presence of secondary metabolites of various chemical types present in the plant species. Our results indicate the potential usefulness of Leptadenia hastata, Barringtonia asiatica and Barringtonia racemosa in the treatment of various pathogenic diseases as it may help in the discovery of new chemical classes of antifungal as well as antibiotic that could serve as selective agents 
for the maintenance of human health and may provide biochemical tools for the study of fungal infectious diseases. This current results demonstrate that selected medicinal plant extracts effective suppressed the radial mycelia growth of all species at various concentration and these findings confirm the result. ${ }^{15-17}$

Table I Effect of methanol root extract of Leptadenia hastata on fungi

\begin{tabular}{|c|c|c|c|c|c|c|c|c|}
\hline \multirow[b]{2}{*}{ Organisms } & \multirow[b]{2}{*}{ Day } & \multirow[b]{2}{*}{ Control } & \multicolumn{5}{|c|}{ Concentration (ppm) } & \multirow[b]{2}{*}{1000} \\
\hline & & & 25 & 50 & 100 & 250 & 500 & \\
\hline & 1 & $0.80 \pm 0.00$ & $0.68 \pm 0.04$ & $0.78 \pm 0.04$ & $0.85 \pm 0.05 b$ & $0.58 \pm 0.04$ & $0.45 \pm 0.05$ & $0.25 \pm 0.05$ \\
\hline & 2 & $1.05 \pm 0.07$ & $0.90 \pm 0.06$ & $1.02 \pm 0.12$ & $1.18 \pm 0.07 b$ & $0.87 \pm 0.05$ & $0.47 \pm 0.05$ & $0.37 \pm 0.05$ \\
\hline \multirow[t]{5}{*}{$\begin{array}{l}\text { Aspergillus } \\
\text { niger }\end{array}$} & 3 & $2.45 \pm 0.07$ & $2.45 \pm 0.05$ & $2.28 \pm 0.08$ & $2.07 \pm 0.05$ & $1.65 \pm 0.05$ & $1.13 \pm 0.10$ & $0.65 \pm 0.05$ \\
\hline & 4 & $3.20 \pm 0.28$ & $3.00 \pm 0.09$ & $2.95 \pm 0.05$ & $2.73 \pm 0.08$ & $2.05 \pm 0.05$ & $1.73 \pm 0.08$ & $1.02 \pm 0.08$ \\
\hline & 5 & $3.65 \pm 0.07$ & $3.38 \pm 0.08 \mathrm{a}$ & $3.27 \pm 0.42 \mathrm{a}$ & $3.75 \pm 0.05 a b$ & $2.62 \pm 0.08 \mathrm{a}$ & $2.15 \pm 0.08 \mathrm{a}$ & $1.23 \pm 0.15 a$ \\
\hline & 1 & $0.95 \pm 0.07$ & $0.80 \pm 0.06$ & $0.80 \pm 0.06$ & $0.95 \pm 0.05$ & $0.80 \pm 0.00$ & $0.67 \pm 0.52$ & $0.47 \pm 0.52$ \\
\hline & 2 & $1.45 \pm 0.07$ & $1.30 \pm 0.06$ & $1.43 \pm 0.05$ & $1.55 \pm 0.05 b$ & $1.18 \pm 0.10$ & $0.95 \pm 0.05$ & $0.73 \pm 0.05$ \\
\hline \multirow[t]{5}{*}{$\begin{array}{l}\text { Aspergillus } \\
\text { flavin }\end{array}$} & 3 & $3.25 \pm 0.07$ & $3.17 \pm 0.05$ & $3.05 \pm 0.05$ & $2.80 \pm 0.00$ & $2.68 \pm 0.12$ & $1.5 \mathrm{I} \pm 0.05 \mathrm{~d}$ & $0.83 \pm 0.12$ \\
\hline & 4 & $3.55 \pm 0.14$ & $3.60 \pm 0.28 \mathrm{a}$ & $3.78 \pm 0.04 \mathrm{ab}$ & $3.75 \pm 0.08$ & $2.37 \pm 0.21$ & $2.08 \pm 0.08 d$ & $1.15 \pm 0.12 \mathrm{~d}$ \\
\hline & 5 & $3.45 \pm 0.07$ & $3.58 \pm 0.08$ & $3.47 \pm 0.05$ & $3.97 \pm 0.08 \mathrm{ab}$ & $3.19 \pm 0.04 a$ & $2.87 \pm 0.05 \mathrm{ad}$ & $1.43 \pm 0.05 a$ \\
\hline & 1 & $1.80 \pm 0.00$ & $1.68 \pm 0.04$ & $1.83 \pm 0.05 b$ & $1.57 \pm 0.05$ & $1.35 \pm 0.05$ & I. $12 \pm 0.08$ & $0.88 \pm 0.08$ \\
\hline & 2 & $2.35 \pm 0.07$ & $2.05 \pm 0.05$ & $2.30 \pm 0.09$ & $2.47 \pm 0.05 b$ & $1.98 \pm 0.08$ & $1.85 \pm 0.05$ & $0.98 \pm 0.08 d$ \\
\hline \multirow{4}{*}{$\begin{array}{l}\text { Candida } \\
\text { tropicalis }\end{array}$} & 3 & $2.25 \pm 0.00$ & $2.42 \pm 0.08$ & $2.48 \pm 0.04$ & $2.67 \pm 0.05$ & $2.85 \pm 0.05 \mathrm{abd}$ & $1.27 \pm 0.15$ & $1.02 \pm 0.08$ \\
\hline & 4 & $2.80 \pm 0.00$ & $2.63 \pm 0.05$ & $2.78 \pm 0.04$ & $2.93 \pm 0.05 b$ & $1.93 \pm 0.08$ & $1.62 \pm 0.04$ & $0.95 \pm 0.05$ \\
\hline & 5 & $3.10 \pm 0.14$ & $2.98 \pm 0.08 a$ & $3.18 \pm 0.04 a$ & $3.33 \pm 0.05 a b$ & $2.68 \pm 0.08$ & $1.75 \pm 0.08 \mathrm{a}$ & $1.20 \pm 0.06 \mathrm{a}$ \\
\hline & I & $2.60 \pm 0.00$ & $2.37 \pm 0.05 d$ & $2.50 \pm 0.89 \mathrm{~d}$ & $2.67 \pm 0.05 \mathrm{bd}$ & $1.93 \pm 0.05 d$ & $1.50 \pm 0.06 \mathrm{~d}$ & $1.02 \pm 0.08 \mathrm{~d}$ \\
\hline & 2 & $2.65 \pm 0.07$ & $2.62 \pm 0.04 d$ & $2.77 \pm 0.05 d$ & $3.00 \pm 0.06 \mathrm{bd}$ & $2.40 \pm 0.06 d$ & $1.92 \pm 0.08 d$ & $0.95 \pm 0.08$ \\
\hline \multirow{3}{*}{$\begin{array}{l}\text { Fusarium } \\
\text { oxysporium }\end{array}$} & 3 & $3.50 \pm 0.14$ & $3.18 \pm 0.12 \mathrm{~d}$ & $3.40 \pm 0.00 d$ & $3.60 \pm 0.06 \mathrm{bd}$ & $2.22 \pm 0.21$ & $1.30 \pm 0.11$ & $1.17 \pm 0.08 \mathrm{~d}$ \\
\hline & 4 & $4.00 \pm 0.00$ & $3.73 \pm 0.05 d$ & $3.93 \pm 0.08 d$ & $4.13 \pm 0.08 \mathrm{bd}$ & $2.67 \pm 0.05 d$ & $1.88 \pm 0.08$ & $0.97 \pm 0.05$ \\
\hline & 5 & $4.70 \pm 0.14$ & $3.90 \pm 0.06 \mathrm{ad}$ & $4.22 \pm 0.08 \mathrm{ad}$ & $4.75 \pm 0.05 \mathrm{ad}$ & $5.00 \pm 0.09 \mathrm{abd}$ & $2.78 \pm 0.39 a$ & $1.57 \pm 0.05 \mathrm{ad}$ \\
\hline
\end{tabular}

Values are Mean $\pm S D$ for six determinations

aSignificantly $(p<0.05)$ higher compared to different treatment days at the same concentration on each fungus

${ }^{b}$ Significantly $(p<0.05)$ higher compared to the control on each fungus in each row

dSignificantly $(p<0.05)$ higher compared to other fungi on the same day on each concentration 
Table 2 Effect of methanol root extract of Barringtonia racemosa on fungi

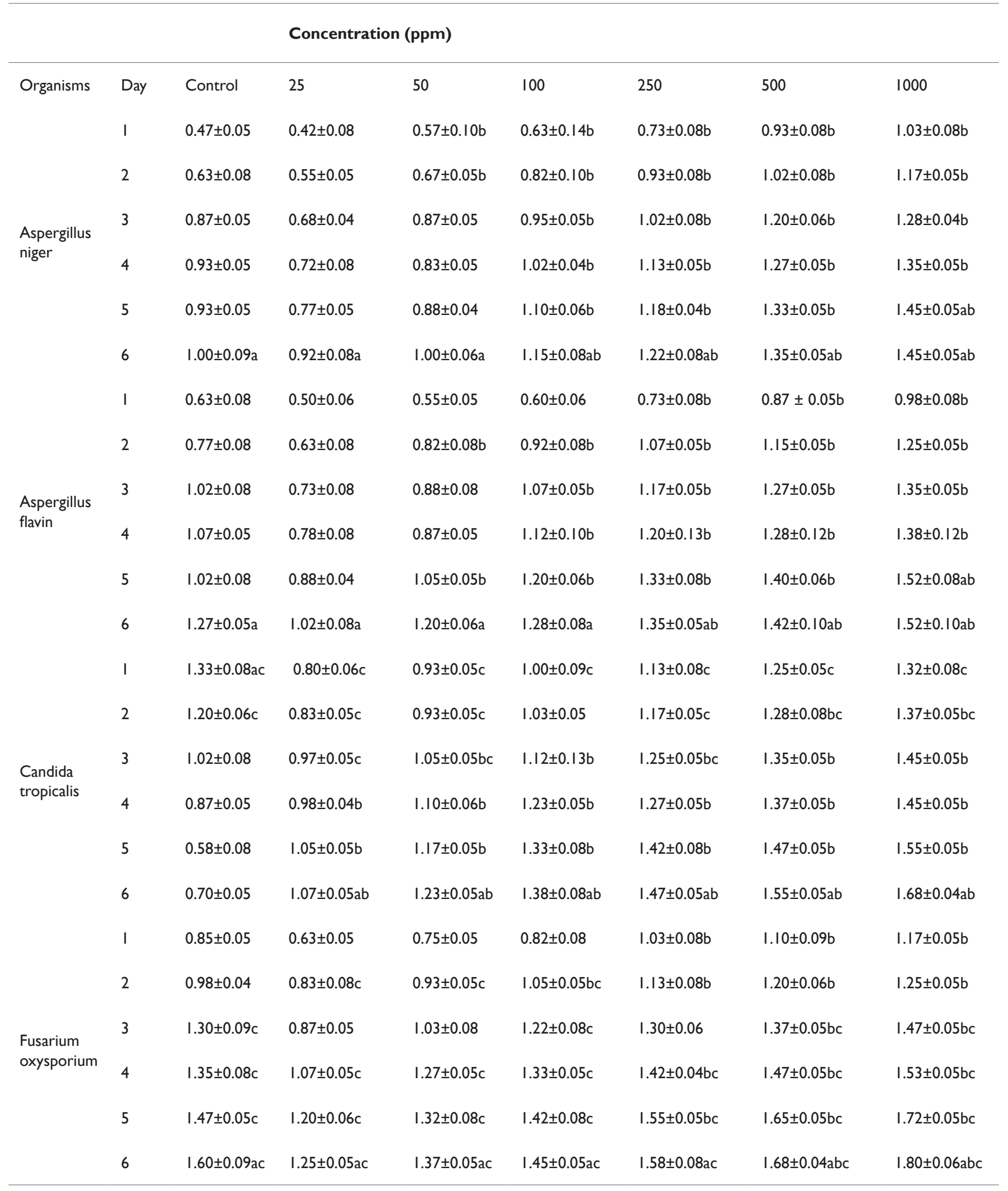

Values are Mean $\pm S D$ for six determinations

aSignificantly $(p<0.05)$ higher compared to different treatment days at the same concentration on each fungi

bSignificantly $(p<0.05)$ higher compared to the control on each fungus in each row

'Significantly $(p<0.05)$ higher compared to other fungi on the same day on each concentration 
Table 3 Effect of methanol root extracts of Barringtonia asiatica on fungi

\begin{tabular}{|c|c|c|c|c|c|c|c|c|}
\hline \multirow[b]{2}{*}{ Organisms } & \multirow[b]{2}{*}{ Day } & \multirow[b]{2}{*}{ Control } & \multicolumn{5}{|c|}{ Concentration (ppm) } & \multirow[b]{2}{*}{1000} \\
\hline & & & 25 & 50 & 100 & 250 & 500 & \\
\hline & 1 & $0.93 \pm 0.04$ & $0.90 \pm 0.06 d$ & $0.97 \pm 0.10 b$ & $0.65 \pm 0.16$ & $0.82 \pm 0.12 d$ & $0.52 \pm 0.12$ & $0.45 \pm 0.19$ \\
\hline & 2 & $1.03 \pm 0.12$ & $0.63 \pm 0.12$ & $0.95 \pm 0.10 \mathrm{~d}$ & $0.58 \pm 0.10$ & $1.05 \pm 0.08$ & $0.90 \pm 0.06 d$ & $0.60 \pm 0.06 d$ \\
\hline \multirow[t]{5}{*}{$\begin{array}{l}\text { Aspergillus } \\
\text { niger }\end{array}$} & 3 & $1.86 \pm 0.11$ & $1.38 \pm 0.23 d$ & $\mathrm{I} .42 \pm 0.3 \mathrm{Id}$ & $1.12 \pm 0.18 d$ & $1.82 \pm 0.15$ & $1.43 \pm 0.14$ & $0.92 \pm 0.08$ \\
\hline & 4 & $I .7 I \pm 0.14$ & $1.05 \pm 0.10 \mathrm{~d}$ & $1.20 \pm 0.14 d$ & $1.18 \pm 0.17 d$ & $1.32 \pm 0.50$ & $\mathrm{I} .40 \pm 0.24 \mathrm{~d}$ & $1.47 \pm 0.14 \mathrm{~d}$ \\
\hline & 5 & $1.67 \pm 0.12$ & $1.48 \pm 0.17 \mathrm{ad}$ & $1.75 \pm 0.55 \mathrm{ad}$ & $\mathrm{I} .12 \pm 0.2 \mathrm{Iad}$ & $1.65 \pm 0.20 \mathrm{ad}$ & $1.32 \pm 0.19 \mathrm{ad}$ & $1.90 \pm 0.06 \mathrm{ad}$ \\
\hline & 1 & $0.87 \pm 0.05$ & $0.75 \pm 0.10$ & $0.85 \pm 0.08$ & $0.67 \pm 0.10$ & $0.72 \pm 0.08$ & $0.60 \pm 0.09$ & $0.55 \pm 0.10$ \\
\hline & 2 & $0.83 \pm 0.08$ & $0.75 \pm 0.08$ & $0.85 \pm 0.08$ & $0.82 \pm 0.08$ & $1.08 \pm 0.08 \mathrm{bd}$ & $0.83 \pm 0.05$ & $0.60 \pm 0.13 d$ \\
\hline \multirow[t]{5}{*}{$\begin{array}{l}\text { Aspergillus } \\
\text { flavin }\end{array}$} & 3 & I. $75 \pm 0.05$ & I. $12 \pm 0.45$ & $1.30 \pm 0.13$ & $1.95 \pm 0.10$ & $1.85 \pm 0.10 d$ & $1.40 \pm 0.19$ & $0.95 \pm 0.05$ \\
\hline & 4 & $1.88 \pm 0.08$ & $1.02 \pm 0.13$ & $1.73 \pm 0.37$ & $1.88 \pm 0.08$ & $1.45 \pm 0.24 d$ & $1.60 \pm 0.25$ & $1.28 \pm 0.15$ \\
\hline & 5 & $1.46 \pm 0.05$ & $1.25 \pm 0.27 \mathrm{a}$ & $1.00 \pm 0.26 \mathrm{a}$ & $1.02 \pm 0.46 \mathrm{a}$ & $1.48 \pm 0.15 a$ & $1.97 \pm 0.23 \mathrm{a}$ & $1.53 \pm 0.12 \mathrm{a}$ \\
\hline & 1 & $0.82 \pm 0.08$ & $0.83 \pm 0.12$ & $1.03 \pm 0.08 \mathrm{bd}$ & $0.87 \pm 0.06 d$ & $0.72 \pm 0.12$ & $0.52 \pm 0.13$ & $0.53 \pm 0.15$ \\
\hline & 2 & $1.00 \pm 0.6$ & $0.87 \pm 0.05 d$ & $0.90 \pm 0.06$ & $0.85 \pm 0.08 d$ & $1.00 \pm 0.06$ & $0.82 \pm 0.07$ & $0.60 \pm 0.06 d$ \\
\hline \multirow[t]{5}{*}{$\begin{array}{l}\text { Candida } \\
\text { tropicalis }\end{array}$} & 3 & $1.10 \pm 0.09$ & $1.055 \pm 0.10$ & $1.07 \pm 0.14$ & $1.98 \pm 0.08$ & $1.60 \pm 0.09$ & $1.53 \pm 0.12$ & $1.15 \pm 0.16 d$ \\
\hline & 4 & $1.39 \pm 0.08$ & $1.00 \pm 0.09$ & I. $15 \pm 0.24$ & $1.07 \pm 0.33$ & $1.90 \pm 0.09$ & $1.48 \pm 0.21$ & $1.05 \pm 0.12$ \\
\hline & 5 & $1.80 \pm 0.08$ & $1.97 \pm 0.05 a$ & $1.80 \pm 0.14 \mathrm{a}$ & $1.28 \pm 0.16 a$ & I. $17 \pm 0.24 \mathrm{a}$ & $1.82 \pm 0.26 \mathrm{a}$ & $1.35 \pm 0.10 \mathrm{a}$ \\
\hline & I & $0.82 \pm 0.08$ & $0.58 \pm 0.08$ & $0.77 \pm 0.08$ & $0.70 \pm 0.09$ & $0.68 \pm 0.08$ & $0.93 \pm 0.10 \mathrm{bd}$ & $0.88 \pm 0.17 \mathrm{bd}$ \\
\hline & 2 & $0.85 \pm 0.05$ & $0.62 \pm 0.10$ & $0.63 \pm 0.05$ & $0.70 \pm 0.06$ & $0.98 \pm 0.08 b$ & $0.80 \pm 0.09$ & $0.53 \pm 0.12$ \\
\hline \multirow[t]{3}{*}{$\begin{array}{l}\text { Fusarium } \\
\text { oxysporium }\end{array}$} & 3 & $1.97 \pm 0.08$ & $1.68 \pm 0.08$ & $1.97 \pm 0.08$ & $2.00 \pm 0.06$ & $1.62 \pm 0.08$ & $1.57 \pm 0.12 \mathrm{~d}$ & $1.07 \pm 0.10$ \\
\hline & 4 & $1.99 \pm 0.08$ & $1.57 \pm 0.05$ & $1.08 \pm 0.15$ & $1.92 \pm 0.08$ & $1.77 \pm 0.12$ & I. $18 \pm 0.23$ & $0.93 \pm 0.14$ \\
\hline & 5 & $1.96 \pm 0.10$ & $1.07 \pm 0.08 a$ & $1.15 \pm 0.19 a$ & $1.05 \pm 0.10 \mathrm{a}$ & $1.97 \pm 0.16 a$ & $1.93 \pm 0.20 \mathrm{a}$ & $1.10 \pm 0.17 \mathrm{a}$ \\
\hline
\end{tabular}

Values are Mean \pm SD for six determinations

aSignificantly $(p<0.05)$ higher compared to different treatment days at the same concentration on each fungus

bSignificantly $(p<0.05)$ higher compared to the control on each fungus in each row

dSignificantly $(p<0.05)$ higher compared to other fungi on the same day on each concentration

\section{Conclusion}

This research work on the three medicinal plant extract as an antifungal show that the efficacy of plants as an antifungal cannot be underestimated, it is showed that all plants extract was found maximally affected against the activity of Aspergillus niger, Aspergillus Flavin, Candida tropicalis and Fusarium oxysporium and aggressively inhibited the growth of species in various plant extracts (Tables 1-3). Thus justify their use in folk medicine for the treatment of skin and other related infections, the plants can as well be used as a probiotic supplements and foods to lower risk of infections, improved digestion and even a reduced risk for some chronic diseases since the leaves can be consumed as vegetable because of its antifungal activities.

\section{Acknowledgments}

None.

\section{Conflict of interest}

Authors declare that there is no conflict of interest.

\section{References}

1. Isaac John Umaru, Fasihuddin A, Zaini B. Antifungal Activity of Leptadenia hastata (Pers) Decne Leaves Extract. Int J Pure App Biosci. 2017;5(6):14-18.

2. Mahesh B, Satish S. Antimicrobial activity of some important medicinal plants against plant and human pathogens. World J Agric Sci. 2008;4:839-843 
3. Adnan M, Hussain J, Shah MT, et al. Proximate and nutrient Composition of Medicinal Plants of Humid and Subhumid regions in Northwest Pakistan. J Med Pl Res. 2010;4(4):339-345.

4. Mann A, Banso A, Clifford LC. An antifungal property of crude plant extracts from Anogeissus leiocarpus and Terminalia avicennioides. Tanzania J Health Res. 2008;10:34-38.

5. Gilani SA, Fujii Y, Shinwari ZK, et al. Phytotoxic studies of medicinal plant species of Pakistan. Pak J Bot. 2010;42(2):987-996.

6. Hussain F, Shaukat SS, Abid M, et al. Some important medicinal plants associated with the vegetation in District Mirpurkhas, Sindh. Int J Biol Biotech. 2012;9(4):405-420.

7. Vuuren SFV, Naidoo D. An antimicrobial investigation of plants used traditionally in southern Africa to treat sexually transmitted infections. $J$ Ethnopharmacol. 2010;130(3):552-558.

8. Bhengraj AR, Dar SA, Talwar GP, et al. Potential of a novel polyherbal formulation BASANT for prevention of Chlamydia trachomatis infection. Int J Antimicrob Agents. 2008;32(1):84-88.

9. Walter C, Shinwari ZK, Afzal I, et al. Antibacterial activity in herbal products used in Pakistan. Pak J Bot. 2011;43:155-162.

10. Verma J, Dubey NK. Prospecdtives of botanical and microbial products as pesticides of tomorrow. Current Sci. 1999;76:172-179.
11. Hussain FM, Abid, Shaukat SS. Ethnobotanical study of Mirpurkhas region in Sindh-Pakistan. Germany. 2014; 224 p.

12. Isaac John Umaru, Fasihuddin Badruddin Ahmed, Hauwa A, et al. Leptadenia hastata (pers) Decne: Phytochemical, Pharmacological, Biotechnological, Botanical, Traditional use and Agronomical aspects. European Journal of Pharmaceutical and Medical Research. 2018;5(6):109-119.

13. Isaac John Umaru, Fasihuddin Badruddin Ahmed, Hauwa A, et al. Umaru Barringtonia racemosa: phytochemical, pharmacological, biotechnological, botanical, traditional use and agronomical aspects. World Journal of Pharmacy and Pharmaceutical Sciences. 2018;7(8):78-121.

14. Isaac John Umaru, Fasihuddin A Badruddin, Zaini B Assima, et al. Antibacterial and Cytotoxicity Studies of Barringtonia Asiatica. Anatomy Physiology and Biochemistry International Journal. 2018;5(3):1-4.

15. Satish S, Mohana DC, Ranhavendra MP, et al. Antifungal activity of some plant extracts against important seed borne pathogens of Aspergillus Sp. J Agric Technol. 2007;3(1):109-119.

16. Bobbarala V, Katikala PK, Naidu KC, et al. Antifungal activity of selected plant extracts against phytopathogenic fungi Aspergillus niger. Indian J Sci \& Technol. 2009;2(4):87-90.

17. Gujar J, Talwankar D. Antifungal potential of crude plant extract on some pathogenic fungi. World J Sci \& Technol. 2012;2:58-62. 